\title{
Peningkatan Hasil Belajar PKn Siswa Menggunakan Metode Team Assisted Individualization (TAI) pada Siswa SD Negeri 050747 Pangkalan Berandan Tahun Pelajaran 2016-2017
}

\author{
Siti Aisyah \\ SD Negeri 050747 Pangkalan Berandan \\ E-mail: sitiaisyah@gmail.com
}

\begin{abstract}
Abstrak
Tujuan penelitian ini adalah untuk meningkatkan hasil belajar siswa dalam pembelajaran PKn. Penelitian ini merupakan penelitian tindakan kelas dengan 2 siklus. Subyek penelitian ini adalah siswa kelas V SD Negeri 050747 Pangkalan Berandan yang berjumlah 28 siswa. Faktor yang diteliti adalah hasil belajar siswa dalam pembelajaran PKn. Pada pra-siklus diketahui nilai rata-rata siswa hanya mencapai 66,25 dengan persentase ketuntasan mencapai 23,33\%. Setelah diterapkan metode Team Assisted Individualization (TAI), hasil belajar siswa mengalami peningkatan. Hal itu terlihat dari nilai rata-rata yang diperoleh pada siklus I mencapai 72,85 dengan pesentase ketuntasan $57,17 \%$ dan pada siklus II nilai rata-rata mencapai 81,07 dengan persentase ketuntasan mencapai 82,14\%. Ini dapat disimpulkan bahwa penerapan metode Team Assisted Individualization (TAI) untuk meninggkatkan hasil belajar siswa SD Negeri 050747 Pangkalan Berandan Tahun Pelajaran 2017-2018 sehingga 58,81\% poin. Oleh karena itu TAI bisa menjadi alternatif metode untuk meningkatkan persentasi ketuntasan belajar siswa.
\end{abstract}

Kata kunci: Hasil Belajar, Metode Team Assisted Individualization (TAI), Penelitian Tindakan Kelas

\begin{abstract}
A proposed study is to improve student learning outcomes in PKn course. This study is a classroom action research with 2 cycles. The subject of this study is the students in grade $V$ of the SD Negeri 050747 Pangkalan Brandan which amounted to 28 students. Studied Factors is the result of student's learning outcome in PKn course. In pre-cycle known the average value of students only reached 66.25 with the percentage of completeness reached $23.33 \%$. After the Team
\end{abstract}


Assisted Individualization (TAI) method was applied, the students' learning outcomes are improved. It can be seen from the average value obtained in the first cycle reached 72.85 with the completeness percentage of $57.17 \%$ and in cycle II the average value reached 81.07 with the percentage of completeness reached $82.14 \%$. It can be concluded that the application of Team Assisted Individualization (TAI) method to improve the students' learning outcomes of SD Negeri 050747 for year $2017-2018$ until $58.81 \%$ points. Therefore TAI can be an alternative method to improve the percentage of students' learning completeness.

Keywords: Learning Outcomes, Team Assisted Individualization (TAI) Method, Classroom Action Research

\section{A. PENDAhULUAN}

Pendidikan nasional merupakan sebuah sistem yang dalam penerapannya menuju tercapainya tujuan pendidikan nasional. Di Indonesia pelaksanaan pendidikan nasional bertitik tolak pada standar nasional pendidikan. Standar nasional pendidikan digunakan sebagai acuan pengembangan kurikulum yang diterapkan pada tiap jenjang pendidikan. Salah satu kurikulum yang digunakan adalah kurikulum tingkat satuan pendidikan (KTSP).

Berdasarkan Peraturan Pemerintah No. 22 Tahun 2006 menyebutkan kurikulum SD/MI memuat delapan mata pelajaran salah satunya yaitu Pendidikan Kewarganegaraan. Tujuan dari mata pelajaran Pendidikan Kewarganegaraan agar peserta didik memiliki kemampuan sebagai berikut: (a) berpikir secara kritis, rasional, dan kreatif dalam menanggapi persoalan hidup maupun isu kewarganegaraan; (b) berpartisipasi dalam segala bidang kegiatan, secara aktif dan bertanggung jawab, sehingga bisa bertindak secara cerdas dalam semua kegiatan dan; (c) berkembang secara positif dan demokratis sehingga mampu hidup bersama dengan bangsa lain di dunia dan mampu berinteraksi, serta mampu memanfaatkan teknologi informasi dan komunikasi dengan baik. Hal ini mudah tercapai jika pendidikan nilai moral dan norma tetap ditanamkan pada siswa sejak usia dini, karena jika siswa sudah memiliki nilai moral yang baik, maka tujuan untuk membentuk warga negara yang baik mudah diwujudkan. 
Depdiknas (2007:25) menemukan permasalahan pada pelaksanaan pembelajaran PKn di SD Negeri 050747 Pangkalan Berandan. Guru kurang maksimal dalam melaksanakan pembelajaran yang partisipatif dan dalam penggunaan media pembelajaran. Selain itu metode pembelajaran dalam Proses Belajar Mengajar (PBM) terkesan sangat kaku, kurang fleksibel, kurang demokratis, dan guru cenderung lebih dominan (one way method). Jika hal demikian tidak diatasi lama kelamaan proses kebosanan dan kejenuhan siswa dapat memuncak berakibat pada menurunnya hasil belajar siswa dan mendapat nilai dibawah KKM yang ditentukan.

Untuk memecahkan masalah pembelajaran tersebut ditetapkan alternatif tindakan untuk meningkatkan hasil belajar dengan menggunakan Metode Team Assisted Individualization (TAI). Bagaimana cara meningkatkan hasil belajar PKn melalui metode Numbered Head Together berbantuan multimedia pada siswa kelas V SD Negeri 050748 Pangkalan Berandan Tahun Pelajaran 2016-2017?

\section{B. TINJAUAN PUSTAKA \\ 1. Pengertian Hasil Belajar}

Menurut Dimyati dan Mudjiono (2002:3-4) hasil belajar merupakan hasil darisuatu interaksi tindak belajar dan tindak mengajar. Dari sisi guru, tindak mengajar diakhiri dengan proses evaluasi hasil belajar. Dari sisi siswa, hasil belajar merupakan berakhirnya penggal dan puncak proses belajar. Hasil belajar, untuk sebagian adalah berkat tindak guru, suatu pencapaian tujuan pengajaran. Pada bagian lain merupakan peningkatan kemampuan mental siswa.

Menurut Suprijono (2011:5) hasil belajar adalah pola-pola perbuatan, nilai-nilai, pengertian-pengertian, sikap-sikap, apresiasi, dan keterampilan-keterampilan yang menurut Gagne dapat berupa: informasi verbal, keterampilan intelektual, strategi kognitif, keterampilan motorik, dan sikap. Dari berbagai pendapat tersebut dapat peneliti tegaskan bahwa hasil belajar adalah perubahan sikap, mental, dan perilaku seseorang meliputi aspek kognitif, afektif, dan psikomotor yang dapat diukur melalui proses penilaian setelah melakukan kegiatan belajar. Dalam penelitian ini, hasil belajar yang dimaksudkan adalah perubahan sikap, mental, perilaku siswa berupa pemahaman terhadap konsep-konsep, fakta-fakta dan prinsip-prinsip 
pelajaran IPA dari yang awalnya belum mengetahui, mengerti, dan memahami, diharapkan setelah dilakukannyapenelitian ini siswa menjadi mengetahui, mengerti, dan memahami konsep tersebut dengan lebih mendalam.

\section{Faktor-faktor yang Memengaruhi Hasil Belajar}

Hasil belajar yang merupakan capaian akhir seseorang dari proses pembelajaran yang dilakukan besarnya sangat dipengaruhi oleh berbagai macam faktor. Menurut Dalyono (2009:55), pencapaian hasil belajar seseorang secara umum dipengaruhi oleh 2 faktor, yaitu faktor internal (berasal dari dalam diri seseorang) dan faktor eksternal (berasal dari luar diri).

Faktor-faktor dari dalam diri seseorang (faktor internal) yang dimaksudkan antara lain:

1. Kesehatan, dalam hal ini tidak hanya dari segi kesehatan jasmani saja melainkan kesehatan rohani seseorang juga sangat memengaruhi hasil belajar;

2. Inteligensi dan bakat, kedua aspek kejiwaan ini memiliki andil yang cukup besar terhadap hasil belajar seseorang;

3. Minat dan motivasi, minat adalah adanya rasa ketertarikan terhadap sesuatu atau untuk melakukan sesuatu, sedangkan motivasi lebih mengarah pada dorongan pada diri seseorang untuk melakukan sesuatu, sesuatu dalam hal ini adalah belajar

4. Cara belajar, belajar tanpa memperhatikan teknik dan faktor fisiologis, psikologis, serta ilmu kesehatan akan memeroleh hasil yang kurang memuaskan.

Sedangkan faktor dari luar diri seseorang (faktor eksternal) yang dimaksudkan antara lain:

1. Keluarga, suasana kehidupan di keluarga, pola hubungan antar anggota keluarga, pendidikan orang tua, dan keadaan ekonomi keluarga seseorang sangat memengaruhi hasil belajarnya;

2. Sekolah, sebagai institusi penyelenggara pendidikan keberadaan sekolah sangatberpengaruh terhadap hasil belajar seseorang.

3. Masyarakat, keadaan masyarakat juga menentukan hasil belajar seseorang. Bila sekitar tempat tinggal keadaan masyarakatnya terdiri dari orang-orang berpendidikan, maka 
semangat belajar anak cenderung akan tinggi dan hasil belajarnya pun tentu akan cenderung tinggi pula.

4. Lingkungan sekitar, lingkungan dalam hal ini lebih dititikberatkan pada kondisilingkungan secara fisik bukan lingkungan dalam arti manusianya atau keadaan.

Lingkungan yang nyaman untuk belajar, jauh dari hiruk pikuk, bersih, tentu sangat nyaman untuk belajar. Namun jika lingkungan sekitar terdiri dari bangunan-bangunan kumuh, bising, kotor, tentu hal ini menyebabkan kenyamanan belajar berkurang. Akibat lebih jauhnya hasil belajar seseorang juga akan rendah.

\section{Model Pembelajaran Team Assisted Individualization (TAI)}

Model pembelajaran Team Assisted Individualization (TAI), merupakan kombinasi pembelajaran kelompok dan individual. Model TAI merupakan model pembelajaran kooperatif yang menekankan pada kemampuan siswa, dimana siswa dikelompokkan berdasarkan kemampuan yang beragam dan setiap siswa memiliki kesempatan untuk sukses dalam mencapai tujuan pembelajaran (Huda, 2011:125). Dalam model pembelajaran TAI, peserta didikditempatkan dalam kelompok - kelompok kecil (4 sampai 5 peserta didik) yang heterogen dan selanjutnya diikuti dengan pemberian bantuan dari guru secara individu bagi yang memerlukannya. Dengan pembelajaran kelompok diharapkan para peserta didik dapat meningkatkan pikiran kritis, kreatifdan menunbuhkan rasa sosial yang tinggi.

Menurut Slavin (2011:195-200) model pembelajaran TAI memiliki delapan komponen. Kedelapan komponen tersebut adalah sebagai berikut:

a. Teams, yaitu pembentukan kelompok heterogen yang terdiri atas 4 sampai 5 peserta didik.

b. Placement Test, yakni pemberian pre-test kepada peserta didik atau melihat rata-rata nilaiharian peserta didik agar guru mengetahui kelemahan peserta didik pada bidang tertentu.

c. Student Creative, melaksanakan tugas dalam suatu kelompok dengan menciptakan situasi di mana keberhasilan individu ditentukan atau dipengaruhi oleh keberhasilan kelompoknya.

d. Team Study, yaitu tahapan tindakan belajar yang harus dilaksanakan oleh kelompok dan guru memberikan bantuan secara individual kepada peserta didik yang membutuhkannya. 
e. Team Scores and Team Recognition, yaitu pemberian skor terhadap hasil kerja kelompok dan pemberian kriteria penghargaan terhadap kelompok yang berhasil secara cemerlang dan memberikan dorongan semangat kepada kelompok yang dipandang kurang berhasil dalam menyelesaikan tugas.

f. Teaching Group, yakni pemberian materi secara singkat dari guru menjelang pemberian tugas kelompok.

g. Facts Test, yaitu pelaksanaan tes-tes kecil berdasarkan fakta yang diperoleh peserta didik.

h. Whole-Class Units, yaitu pemberian materi kembali di akhir waktu pembelajaran oleh guru dengan strategi pemecahan masalah.

Pembelajaran TAI adalah salah satu tipe atau model pembelajaran kooperatifyang mudah diterapkan, melibatkan, aktivitas seluruh pesertadidik tanpa harus ada perbedaan status, melibatkan peranpeserta didik sebagai tutor sebaya dan mengandung unsurpermainan dan reinforcement. Model pembelajaran kooperatiftipe ini menekankan bahwa individu yang belum memahami materi merupakan tanggung jawab anggota kelompok lain sehingga anggota yang sudah paham perlu memberikan bantuan kepada anggota lain yang belum paham. Dengan demikian, secara ringkas sintak model ini sebagai berikut:

a. Pembentukan kelompok atas dasar heterogenitas.

b. Pemberian bahan ajar, dapat berbentuk modul atau LKS.

c. Pembelajaran dalam kelompok, peserta didik yang belum paham dibantu oleh peserta didik yang pandai dalam satu kelompok secara individual atau dapat dikatakan peer tutor.

d. Pengerjaan kusi atau ujia.

e. Refleksi dan umpan balik dari guru.

\section{Langkah - langkah model pembelajaran TAI}

Model pembelajaran TAI kombinasi pembelajaran kelompok yang dikembangkan oleh Slavin (1985) mempunyai langkah-langkah sebagai berikut.

a. Disampaikan tujuan pembelajaran.

b. Guru membagi kelas dalam beberapa kelompok heterogen.

c. Setiap peserta didik belajar pada aspek khusus pembelajaran secara individual. 
d. Anggota kelompok menggunakan lembar yang digunakan untuk saling memeriksa jawaban teman satu kelompok.

e. Semua bertanggung jawab atas keseluruhan jawaban pada akhir kegiatan sebagai tanggung jawab bersama.

f. Validasi kelas hasil diskusi kelompok.

g. Guru memberikan penilaian.

h. Kesimpulan dan Penutup

Model pembelajaran kooperatif TAI adalah model pembelajaran dimanapeserta didik belajar berkelompok atau tim, setiap angggota kelompok menyelesesaikan tugas dalam Lembar Kerja, kemudian anggota kelompok mendiskusikan untuk mendapatkan simpulan dan akhirnya di berikan satu permasalahan yang harus diselesiakan oleh setiap anggota kelompok.

Model pembelajaran tipe ini akan membentuk peserta didik mampu berkomunikasi sendiri dalam kelompoknya dengan bahasa anak itu sendiri, sehingga sangat mudah untuk saling memberi dan menerima kekurangan, serta peserta didik dapat berdiskusi dengan baik antar peserta didik dalam kelompoknya. Menurut Slavin (2011) adapun tahap-tahap pembelajaran kooperatif tipe Team Assisted Individualization (TAI) dalam kelas adalah sebagai berikut:

\section{Tahap I: Tahap Pendahuluan}

1) Review, Apersepsi, Motivasi

2) Pembentukan kelompok.

\section{Tahap II: Tahap Penguasaan}

1) Setiap peserta didik belajar pada aspek khusus pembelajaran secara individual.

2) Setiap kelompok menggunakan lembar jawab yang digunakan untuk saling memeriksa jawaban teman satu kelompok.

3) Semua bertanggung jawab atas`keseluruhan jawaban pada akhir kegiatan sebagai tanggung jawab bersama

\section{Tahap III: Tahap Validasi}

1) Hasil diskusi kelas sabahgai validasi

2) Guru menguatkan hasil validasi kelas

\section{Tahap IV: Penutup}

1) Peserta didik bersama dengan guru membuat kesimpulan

2) Guru memberi permasalahan baru yang harus diselesaikan secara individual.

3) Pemberian tugas 


\section{METODE}

Penelitian ini dilakukan di Sekolah Dasar (SD) Negeri 050747 P. Berandan semester ganjil Tahun Pelajaran 2016-2017 dengan jumlah siswa sebanyak 28 orang. Metode penelitian yang digunakan adalah Penelitan Tindakan Kelas (PTK) yang terdiri dari 2 siklus. Pelaksanakaan penelitian ini dengan menggunakan model yangdikemukakan oleh Kemmis dan Mc. Taggart (1990). Siklus I dilaksanakan dari tahap perencanaan, pelaksanaan tindakan, Observasi dan refleksi. Hasil siklus I digunakan untuk perbaikan-perbaikan pada siklus II. Pada tahap siklus II masih dilaksanakan seperti siklus I.

Teknik pengumpulan data yang digunakan yaitu teknik tes. Teknik tes digunakan untuk mengukur hasil belajar siswa yaitu dari hasiltes formatif siswa pada siklus I dan siklus II. Tes formatif dilaksanakan pada setiap akhir siklus. Hasil tes formatif siswa juga digunakan untuk menghitung nilai rata - rata kelas dan menghitung tuntas belajar klasikal.

Analisis data dilakukan setelah pengumpulan data diperoleh. Berdasarkandata dan hasil pengolahan data yang telah terkumpul, kemudian dianalisis. Adapun untuk menghitung hasil belajar dan persentase ketuntasan siswa adalah sebagai berikut ini:

Nilai Siswa $=\frac{\text { skormentah }}{\text { SkorMaksimumIdeal }} \times 100$

Persentase ketuntasan belajar $=\frac{n}{N} \times 100 \%$

Dimana $n=$ Jumlah siswa yang mendapat nilai $\geq 75$ dan $N=$ Jumlah seluruh siswa. Indikator Keberhasilan yang ditentukan dapat tercapai apabila 80\% siswa kelas V SD Negeri 050748 Pangkalan Berandan Tahun Pelajaran 2016-2017 mendapatkan nilai 75.

\section{HASIL DAN PEMBAHASAN}

1. Hasil

Sebelum melakukan penelitian, peneliti memberikan instrument test kepada siswa. Hal ini dilakukan untuk mengetahui seberapa besar hasil belajar siswa terhadap materi pembelajaran yang akan diajarkan. Dari hasil instrument test awal ini, peneliti melihat bahwa rendahnya hasil belajar siswa terhadap pembelajaran ini, dimana pada test tersebut hanya sebagian kecil siswa yang mampu 
lulus KKM (75) dan sebagian besarnya lagi siswa cenderung di bawah KKM dan termasuk ke dalam kategori buruk. Berdasarkan data yang diperoleh bahwa hasil belajar siswa SD Negeri 050747 Pangkalan Berandan Tahun Pelajaran 2016-2017 sebelum diberikannya tindakan sangat rendah. Hal itu terlihat dari jumlah nilai rata-rata yang diperoleh mencapai hanya mencapai 66,25 dengan persentase ketuntasan hanya $23,33 \%$ atau hanya 7 orang siswa yang mendapat nilai tuntas belajar. Melihat hasil belajar yang sangat rendah terhadap pembelajaran PKn maka untuk itu peneliti akan melanjutkan penelitian kesiklus I.

Pada siklus I, hasil belajar siswa mengalami peningkatan setelah diberikan. Hal itu terlihat dari nilai rata-rata yang diperoleh meningkat menjadi 72,85 dengan persentase ketuntasan $57,17 \%$ atau 16 orang siswa mendapatkan nilai tuntas belajar. Sedangkan pada siklus II, hasil belajar siswa semakin meningkat. Hal itu dapat dilihat dari nilai rata-rata mencapai 81,07 dengan persentase ketuntasan mencapai $82,14 \%$. Hasil ini diperoleh karena siswa sudah mengerti bagaimana mengikuti pembelajaran $\mathrm{PKn}$. Secara ringkas di gambarkan dalam gambar 1 berikut

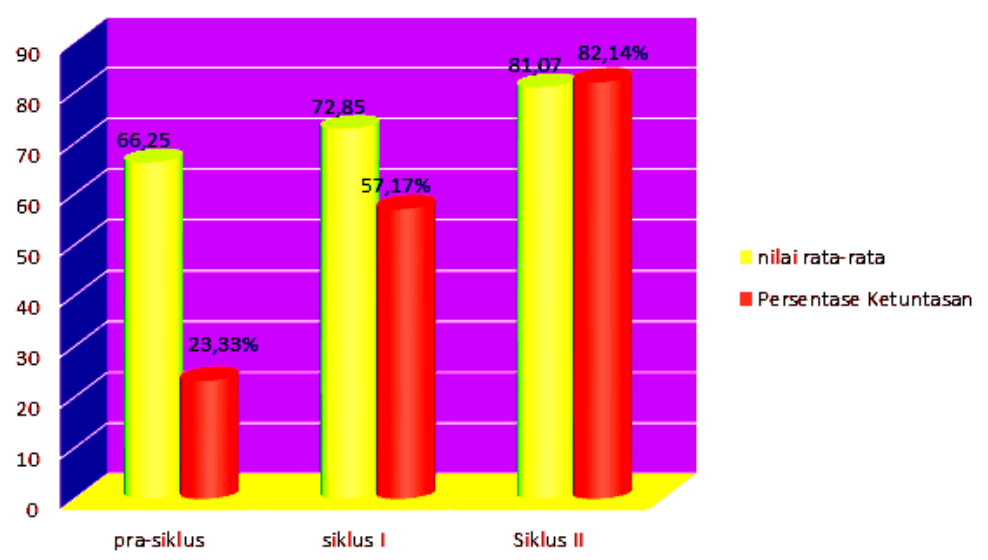

Gambar 1. Diagram Peningkatan Hasil Belajar PKn Siswa

\section{Pembahasan}

Berdasarkan hasil obeservasi awal, diketahui bahwa hasil belajar PKn siswa kelas V SD Negeri 050747 Pangkalan Berandan Tahun Pelajaran 2016-2017 masih rendah. Hal ini dikarenakan siswa merasa bosan dengan mata pelajaran PKn yang ditandai dengan 
beberapa orang siswa mengantuk dan banyak yang keluar masuk serta sebagian besar sibuk dengan kegiatannya masing-masing (mengobrol dengan berbisik-bisik dan sesekali tertawa) tanpa memperhatikan penjelasan guru, metode yang digunakan cenderung monoton dengan metode ceramah sehingga guru terkesan menguasai kelas.

Maka dari itu peneliti berupaya untuk membantu siswa SD Negeri 050747 Pangkalan Berandan khususnya pada siswa kelas V untuk meningkatkan hasil belajar PKn dengan menggunakan metode TAI. Pada observasi awal sebelum diberikannya tindakan, hasil belajar PKn siswa kelas V SD Negeri 050747 Pangkalan Berandan Tahun Pelajaran 2016/2017 sangat rendah.

Setelah diterapkannya penggunaan metode TAI, hasil belajar PKn mengalami peningkatan. Hal itu terlihat dari persentase ketuntasan belajar siswa pada siklus I meningkat dari 23,33\% menjadi $57,17 \%$, kemudian siklus II persentase ketuntasan semakin meningkat dari $57,17 \%$ menjadi $82,14 \%$ dengan nilai rata-rata 81,07.

\section{E. SIMPULAN}

\section{Kesimpulan}

Berdasarkan data yang diperoleh dalam penelitian ini dapat ditarik kesimpulan bahwa dengan menggunakan metode Team Assisted Individualization (TAI) dapat meningkatkan hasil belajar PKn pada siswa. Simpulan ini berdasarkan observasi bahwa :

a. Hasil penelitian menunjukkan bahwa hasil belajar PKn pada materi pentingnya menjaga keutuhan Indonesia sebelum diberikan tindakan hanya memperoleh nilai rata-rata 66,25. Setelah dilakukan tindakan pembelajaran berupa pemberian metode Team Assisted Individualization (TAI) rata-rata nilai hasil belajar pada siklus I sebesar 72,85, Sedangkan pada siklus II diperoleh nilai rata-rata 81,03 .

b. Hasil penelitian menunjukkan bahwa persentase ketuntasan belajar siswa juga meningkat disetiap siklus. Diketahui pada prasiklus diketahui bahwa persentase ketuntasan belajar siswa hanya mencapai $23,33 \%$, pada siklus I mencapai $57,17 \%$ dan pada siklus II mencapai $82,14 \%$. 


\section{Saran}

Sehubungan dengan simpulan penelitian ini, peneliti mengemukakan saran kepadaguru Matematika sebagai berikut:

a. Untuk meningkatkan hasil belajar PKn pada materi pentingnya menjaga keutuhan Indonesia dengan menggunakan metode Team Assisted Individualization (TAI) dapat dijadikan sebagai salah satu altenatif guru dalam melakukan kegiatan pembelajaran di kelas.

b. Guru dalam mendidik siswa harus lebih sabar dan mengarahkan siswa dalam proses pembelajaran agar siswa aktif, disiplin, dan mengerjakan tugas dengan penuh rasa tanggung jawab.

c. Setelah siswa menyelesaikan tugas, hendaknya guru memberikan komentar tentang kekurangan dan kelebihan siswa.

\section{F. DAFTAR PUSTAKA}

Dalyono. 2009. Psikologi Pendidikan. Jakarta: Rineka Cipta.

Dimyati dan Mujiono. 2002. Belajar dan Pembelajaran. Jakarta: Rineka Cipta.

Huda, M. 2011. Cooperative Learning: metode, teknik, struktur, dan model penerapan. Yogyakarta: Pustaka Pelajar

Slavin, R.E. 1985. Cooperatif Learning Teori, Riset dan Praktik. Bandung: Nusamedia.

2011. Cooperatif Learning Teori, Riset dan Praktik. Bandung: Nusamedia.

Suprijono. 2011. Model-Model Pembelajaran. Jakarta: Gramedia Pustaka Jaya. 